\title{
$X X$
}

\section{Ethnomethodology and the Visual: Practices of Looking,}

\section{Visualization, and Embodied Action}

\author{
Michael Ball and Gregory Smith
}

\section{INTRODUCTION}

Ethnomethodology (hereafter EM) occupies a unique position in contemporary sociology. It has developed within academic sociology but is at odds with many, if not most, of sociology's methods, approaches, and presuppositions. Yet it retains enough of an emphasis on the fundamental sociality of action and cognition to be frequently described as a species of micro-sociology. Ethnomethodologists often prefer to regard EM as an 'alternative sociology' - a radically different way of doing sociological investigation (Lynch and Sharrock, 2003).

At the heart of this alternative sociology is a sustained commitment to study empirically the characteristics of actual social practices. The social world that sociologists study is full of people doing things that seem ordinary to them such as standing in line, having a conversation, giving directions, and figuring out a math problem. Such ordinary social actions or practices are the 'stuff' of social life. What sets EM apart from most other sociological approaches is its determination to observe and analyze ordinary social practices as they actually occur. EM is critical of 'typical' or 'idealized' or 'representative' or 'imagined' renderings of practices. This preoccupation with analyzing actual social practices and their components is evident in the studies reviewed in this chapter. Topics covered include queues, glances, directional maps and signs, mammograms, astronomical discoveries, courtroom testimony, and the teaching of new surgical procedures. EM casts fresh light on how the visual properties of these and many 
other everyday practices are socially organized. In this endeavor to capture and analyze the actualities of social practices, photographic and video technologies have proved invaluable in providing recordings of the details of actions that EM considers so central.

Since its inception, EM has maintained an abiding concern with the visual dimension of everyday social life-what its founder, Harold Garfinkel (1917-2011) termed the looks of things. ${ }^{1}$ An appreciation of the importance of how the world looks to its members, of how the orderliness and intelligibility of ordinary human action critically depends upon its appearance, has led ethnomethodologists to accord the visual dimension an important role in their analyses. In addition, ethnomethodology's openness to the deployment of new technologies to collect data and facilitate analysis has ensured that the visual has always been accorded significance within this perspective.

Garfinkel has long acknowledged both the significance of the visual dimension in social life and the issues of representation posed by sociological investigation. Garfinkel's early (1948) manuscript published under the title, Seeing Sociologically (Garfinkel, 2006), stressed the primordial character of ordinary acts of looking and hearing. His major statement (Garfinkel, 1967) included such standard graphical forms as tables and tree diagrams. It also included a novel textual format to attempt to represent the background understandings informing ordinary conversations (see Garfinkel, 1967: 25-26, 38-39). Our discussion first turns to a review of visuality in Garfinkel's work.

\section{GARFINKEL AND THE LOOKS OF THINGS, CONCEIVED ETHNOMETHODOLOGICALLY}

Since its emergence in the 1960s, EM has made distinctive contributions to visual studies. To understand this contribution, it is necessary to consider some of the theoretical and methodological emphases that have made EM a unique sociological perspective. Garfinkel's now classic work, Studies in Ethnomethodology (Garfinkel, 1967; see also Garfinkel, 2002, 2006), established a project that was developed by a group of similarly minded scholars who recognized the conceptually and methodologically 
radical character of the venture that he initiated. Although often misunderstood and, in many respects, still in process of being worked out, EM's concerns and a number of its characteristic ideas have attracted a multi-disciplinary audience. The close analytic attention given to all forms of practical action that EM recommends has found ready audiences beyond academic sociology wherein EM originated. EM has inspired empirical research and scholarship in a variety of domains, including studies of work, organizational practices, practical reasoning, conversation analysis, phenomenological investigations, and studies of visual analysis and visual competencies.

EM's distinctive approach to social actions can be understood as a radical re-specification of Durkheim's famous aphorism that can be summarized in the statement: 'the objective reality of social facts is sociology's most fundamental phenomenon' (Rawls, 2002: 20). Garfinkel (1967, 2002) draws upon a neglected theme in Durkheim's thought: namely, social facts are constructed out of the specific and concrete details of social actions. The constant attention to what actually transpires in specific situations distinguishes EM from those many kinds of social science that are content to proceed on the basis of generalized descriptions of social practices and ideal-typical models of what it is believed motivates persons' actions. Garfinkel maintained that the orderliness of social action arises from the orderliness of the specific details of the action on any actual occasion. These details of social actions were orderly because they were socially organized, and thus could be studied sociologically. EM sought to investigate the methodical or orderly character of ordinary social actions. It especially focused upon the procedural bases of social activities: how, exactly, were actions built up out of their constituent details? It empirically investigated the methodical ways in which, for example, jurors make decisions, conversationalists produce and respond to an interruption, astronomers make discoveries in the course of a night's work in the observatory. One feature of the construction of activities is that they are 'reflexively accountable': that is, they are assembled so as to display their recognizability for whatever they are. In the details of their construction, a reasonably founded juror's decision, an interrupted turn at talk, a new astronomical object discovered, can each be recognized by competent members of society (jurors, conversationalists, astronomers) for what they are. Members of society unavoidably do the production and recognition of 
ordinary actions locally, in situ. Actions are 'indexical' in that their specific sense on any actual occasion is tied to a multitude of features of the local social context. These contextual features include identities and relationships acknowledged, resources mobilized, and aims pursued. In other words, the recognition and production of ordinary social actions is a practical, everyday accomplishment of society members. Producing and making sense is a demand facing all members of society-as Garfinkel notes, there is 'no time out ... no possibility of evasion' (1988: 103) from this ineluctable demand. At the heart of EM's empirical investigations is the study of the methods of how members make sense of and put together those actions-how they are recognized and produced.

Garfinkel captured this concern with the essential observability of the details of daily life as follows:

The idea is this: worldly objects, as of the cogency and the cohesion of details, are available in the looks of organizational Things. If not, then where else in the world are you going to find them?

Ethnomethodologically, they are available in an instructably observable arrangement, of apparent details - of details in and as their coherence producedly provided for. (2002: 211)

In contrast to many traditions in sociology, the visual dimension within EM studies is integral to the enterprise. As Baccus (1986) argued, "That visibility is a "criterion" for the real-worldliness of social objects is to say that social objects, the objects of analytic social theorizing are constituted so as to provide for their visibility via some means' (1986: 6). For normally sighted persons numerous courses of embodied action involve a powerful and inescapable visual dimension.

In a later study, Garfinkel employed a collection of photographic images to show how instructions and instructed actions function in everyday contexts. One example features a photograph of the layout and visual appearance of things in Helen's kitchen (see Exhibit 3 in Garfinkel, 2002: 213). Helen is a sightimpaired person. It was consequently important that within her kitchen there was a visual order and clear spatial relationship between relevant things, so that they were readily locatable for her to work in her kitchen. So, for example, several cooking implements are hung from hooks on the wall behind the oven. The range of cooking implements displayed a visual spatial pattern or organization with which Helen was 
familiar, for very good practical reasons. Her sight impairment required much scanning on her part to locate implements and ingredients when preparing a meal. Even with sight impairment, Helen was able to locate what she needed efficiently. Constructing a spatial layout for tools, implements and materials that is visually clear is a common practice in many workshops, garages, offices, and the like. In the case of people with sight impairment, such organization takes on a greater practical significance, revealing aspects of the 'endogenously produced coherent appearances of Things' (Garfinkel, 2002: 211).

\section{SITUATING ETHNOMETHODOLOGY}

The distinct analytic orientation of EM can be better understood if it is compared with some other leading approaches in visual studies (see Table X.1). Very briefly: compared with content analysis, EM is a qualitative not quantitative approach; compared with semiotics, EM sees meaning as more contextual and less a matter of sign relationships; compared with psychoanalysis, it is much more focused on people's conduct - what they say and do-rather than their conscious and unconscious mental life; and compared with symbolic interactionism (to which it stands closest), EM is likewise much concerned with the participant's point of view but is more attentive to the contextual particulars of talk and action as a source of the understandings and orientations that guide participants' actions (Ball and Smith, 1992). We hope that similarities and differences between EM and these other popular approaches in visual studies will become clearer as the chapter's review of studies proceeds.

The chapter examines how researchers working in the tradition of EM have addressed the visual dimension in their research studies. Its orientation is broadly historical and methodological. As an organizing device, we have stressed the role of technological developments in recording devices. A summary statement is given in Table X.2, 'Ethnomethodology, visuality, and its technological assists.' In speaking of technological assists, we want to highlight the opportunities new technologies have lent EM inquiries. We hope that it goes without saying that we disavow any suggestion that determinism is involved in accounting for the development of the field of visual EM studies in this way. It remains, we stress, nothing more than an organizing device designed to highlight the various ways in which visual data 
have been gathered for EM analysis. That said, it is notable that at the low-technology end of EM research,

EM- inspired ethnographic research shares much in common with well-known classics of ethnographic research. However at the high-technology end of our schema, researcher-generated audio-video recordings of indigenous uses of images, there is a degree of technological sophistication that lies far beyond the imagination of even a Malinowski or a Park.

Table X.1 Comparison of ethnomethodology with other perspectives in visual studies

\begin{tabular}{|c|c|c|c|c|c|}
\hline & Ethnomethodology & Content analysis & Semiotics & Psychoanalysis & $\begin{array}{c}\text { Symbolic } \\
\text { interactionism }\end{array}$ \\
\hline $\begin{array}{l}\text { Key } \\
\text { questions }\end{array}$ & $\begin{array}{l}\text { What are the methods } \\
\text { that people use to } \\
\text { produce and recognize } \\
\text { the practices of } \\
\text { ordinary social life? }\end{array}$ & $\begin{array}{l}\text { What are the } \\
\text { significant } \\
\text { categories and } \\
\text { themes } \\
\text { predominant in } \\
\text { any } \\
\text { communication? }\end{array}$ & $\begin{array}{l}\text { What do signs } \\
\text { mean within socio- } \\
\text { cultural contexts? }\end{array}$ & $\begin{array}{l}\text { How are } \\
\text { spectators and } \\
\text { visual images } \\
\text { mutually } \\
\text { constituted? How } \\
\text { are 'repressed' } \\
\text { instincts allowed } \\
\text { licensed } \\
\text { expression? }\end{array}$ & $\begin{array}{l}\text { How are meanings } \\
\text { created and } \\
\text { sustained in social } \\
\text { interaction? }\end{array}$ \\
\hline $\begin{array}{l}\text { Aim of } \\
\text { analysis }\end{array}$ & $\begin{array}{l}\text { Elucidation of people's } \\
\text { methods for producing } \\
\text { and recognizing } \\
\text { features of social } \\
\text { practices. Analysis } \\
\text { shows how social } \\
\text { practices are made } \\
\text { 'accountable': i.e. } \\
\text { observable and } \\
\text { reportable }\end{array}$ & $\begin{array}{l}\text { Identification of } \\
\text { patterns of } \\
\text { messages. } \\
\text { Manifest and } \\
\text { latent contents of } \\
\text { communication }\end{array}$ & $\begin{array}{l}\text { Discovery of how } \\
\text { signs work to } \\
\text { convey socio- } \\
\text { cultural meaning }\end{array}$ & $\begin{array}{l}\text { Exploration of how } \\
\text { unconscious } \\
\text { motives, usually } \\
\text { linked to sexual } \\
\text { desire, manifest } \\
\text { themselves in acts } \\
\text { of looking by } \\
\text { audiences }\end{array}$ & $\begin{array}{l}\text { Analytic description; } \\
\text { concept generation } \\
\text { and development }\end{array}$ \\
\hline Exemplars & $\begin{array}{l}\text { Sacks (1972); Mondada } \\
\text { (2003) }\end{array}$ & $\begin{array}{l}\text { Robinson (1976); } \\
\text { Lutz and Collins } \\
\text { (1993) }\end{array}$ & $\begin{array}{l}\text { Barthes (1977); } \\
\text { Williamson (1978) }\end{array}$ & $\begin{array}{l}\text { Mulvey (1975); } \\
\text { Doane (1991) }\end{array}$ & $\begin{array}{l}\text { Goffman (1979); } \\
\text { Chalfen (1987) }\end{array}$ \\
\hline
\end{tabular}




\begin{tabular}{|c|c|c|c|c|c|}
\hline $\begin{array}{l}\text { Units and } \\
\text { topics of } \\
\text { analysis }\end{array}$ & $\begin{array}{l}\text { Social practices and } \\
\text { specifically socially } \\
\text { situated talk and } \\
\text { visually available } \\
\text { behavior }\end{array}$ & $\begin{array}{l}\text { Texts that contain } \\
\text { messages } \\
\text { communicated } \\
\text { from a source to a } \\
\text { receiving audience }\end{array}$ & $\begin{array}{l}\text { Signifiers and their } \\
\text { signifieds and } \\
\text { referents; relations } \\
\text { between signs } \\
\text { (syntagmatic and } \\
\text { paradigmatic) }\end{array}$ & $\begin{array}{l}\text { Films and film } \\
\text { genres }\end{array}$ & $\begin{array}{l}\text { Symbols, their } \\
\text { interactional } \\
\text { currency and } \\
\text { significance }\end{array}$ \\
\hline $\begin{array}{l}\text { Attention } \\
\text { to visual } \\
\text { data }\end{array}$ & $\begin{array}{l}\text { Observations and } \\
\text { recordings of visual } \\
\text { aspects of talk and } \\
\text { activity. }\end{array}$ & $\begin{array}{l}\text { Drawings, images, } \\
\text { photographs, and } \\
\text { paintings that can } \\
\text { be collected and } \\
\text { coded into } \\
\text { predetermined } \\
\text { categories }\end{array}$ & $\begin{array}{l}\text { Photographic } \\
\text { images, advertising } \\
\text { images analyzed } \\
\text { by semiotic } \\
\text { conceptual } \\
\text { terminology }\end{array}$ & $\begin{array}{l}\text { The filmic text as a } \\
\text { vehicle to explore } \\
\text { a range of } \\
\text { unconscious } \\
\text { fantasies and } \\
\text { desires such as } \\
\text { scopophilia }\end{array}$ & $\begin{array}{l}\text { Participant and direct } \\
\text { observation to } \\
\text { examine } \\
\text { interactional uses of } \\
\text { images and pictorial } \\
\text { forms (for example, } \\
\text { advertisements, } \\
\text { snapshot } \\
\text { photography) }\end{array}$ \\
\hline $\begin{array}{l}\text { Conception } \\
\text { of the } \\
\text { research } \\
\text { subject's } \\
\text { human } \\
\text { nature }\end{array}$ & $\begin{array}{l}\text { A skilled social agent } \\
\text { constantly making } \\
\text { sense of everyday } \\
\text { situationsand ordinary } \\
\text { actions }\end{array}$ & $\begin{array}{l}\text { An absorber of } \\
\text { messages. } \\
\text { Meaning of } \\
\text { message for the } \\
\text { receiver assumed } \\
\text { to be identical to } \\
\text { that of the sender }\end{array}$ & $\begin{array}{l}\text { Persons placed in } \\
\text { subject positions } \\
\text { by semiotic codes }\end{array}$ & $\begin{array}{l}\text { Emotional states } \\
\text { such as dreams } \\
\text { and fantasies, } \\
\text { often repressed by } \\
\text { the unconscious, } \\
\text { are the key } \\
\text { tohuman } \\
\text { subjectivity }\end{array}$ & $\begin{array}{l}\text { A skilled social agent } \\
\text { at home with specific } \\
\text { cultural repertoires }\end{array}$ \\
\hline $\begin{array}{l}\text { Conception } \\
\text { of the } \\
\text { social } \\
\text { world } \\
\text { premised } \\
\text { by analysis }\end{array}$ & $\begin{array}{l}\text { An emphasis on the } \\
\text { constructed character } \\
\text { of social practices and } \\
\text { the particularities of } \\
\text { their contexts }\end{array}$ & $\begin{array}{l}\text { A web of messages } \\
\text { exchanged by } \\
\text { senders and } \\
\text { receivers }\end{array}$ & $\begin{array}{l}\text { A multiplicity of } \\
\text { codes. Certain } \\
\text { codes become } \\
\text { dominant } \\
\text { ideologies }\end{array}$ & $\begin{array}{l}\text { Civilization } \\
\text { represses instincts } \\
\text { to enforce social } \\
\text { conformity via law, } \\
\text { taboo, etc. }\end{array}$ & $\begin{array}{l}\text { A vast network of } \\
\text { interactants }\end{array}$ \\
\hline
\end{tabular}

This shift toward more technologically sophisticated methods of data collection has helped to shape the broad direction taken by more than four decades of visual EM research. Earlier studies tended to concentrate on the 'practices of looking' used by individuals in varying capacities, while more recent studies increasingly focus on 'practices of visualization.' What do we mean by this distinction?

Our contention is that Garfinkel's appreciation of visuality in ethnomethodological inquiry was taken forward by ethnographic studies of public, formal organizational, and occupational settings. The visual orientations of early EM concentrated on aspects of, in the phrase popularized by Goffman (1963), 'behavior in public places' - studies of using directional signs to find one's way about, glancing, urban 
walking, making inferences based on appearances about the moral character of passers-by, queuing, and the like. These studies are investigations of 'practices of looking' within the natural attitude of everyday life. The aim was to articulate those visual features of public places that members of society noticed and used as a basis for their action. Some of this research drew upon still photographic images, film, or video data. The visual dimension also figured in conversation analysis (CA), the first significant methodological development to emerge out of EM (Francis and Hester, 2004). This may seem paradoxical since CA concentrates on what can be heard rather than seen. However, CA was significant for its principled dependence on recorded audio materials to facilitate the close analytical scrutiny of conversation, or what Schegloff (1987) more accurately came to refer to as 'talk-in-interaction.' The relevance of CA was to show how the analytical sensitivities of EM could address a variety of practices, in which the visualization of an object, course of action or scene was central. The concern with 'practices of visualization' has generated a rich research program that has included forms of pedagogy and instructed action, scientific investigation and workplace studies, in a range of organizational and occupational contexts where practitioners are faced with the task of working with visual images. This research has exploited the potential of video technology as a method of data collection in order to study the working practices of those who themselves work with images, in locations such as security camera surveillance centers, operating theaters, or control rooms. Subsequently, this considerable research tradition, often referred to as multimodal video analysis, has turned its methodology to ordinary social actions in everyday contexts such as crossing the road (Merlino and Mondada 2018).

Table X.2 Ethnomethodology, visuality, and its technological assists

\begin{tabular}{|l|l|l|}
\hline \multicolumn{1}{|c|}{ Source of data } & \multicolumn{1}{|c|}{ Approach } & \multicolumn{1}{|c|}{ Representative studies } \\
\hline Ethnographic research & EM-inspired studies of social (and & Bittner (1967) on policing on skid row \\
& especially work) practices that include & Cicourel (1968) on juvenile justice \\
& visual arrangements, using data & Sudnow (1978, 2001) on jazz \\
& collected by conventional ethnographic & improvisation \\
& observational and interviewing & Sudnow (1972) on the timing of glances \\
& techniques & \\
\hline
\end{tabular}




\begin{tabular}{|c|c|c|}
\hline Found images and documents & $\begin{array}{l}\text { Analysis of found images and records- } \\
\text { and how people use these objects in } \\
\text { courses of action }\end{array}$ & $\begin{array}{l}\text { Psathas (1979) on directional maps } \\
\text { Garfinkel (1967) on psychiatric clinic records } \\
\text { Slack et al. (2007) on reading mammograms }\end{array}$ \\
\hline Audiotaped recordings & $\begin{array}{l}\text { Canonical CA: talk as social-action- } \\
\text { based transcribed data of naturally } \\
\text { occurring conversations. Visuality is } \\
\text { secondary to the treatment of talk }\end{array}$ & $\begin{array}{l}\text { Sacks (1972) on conversational data } \\
\text { Schegloff (1972) on place formulations } \\
\text { Garfinkel et al. (1981) on scientific discoveries }\end{array}$ \\
\hline $\begin{array}{l}\text { Researcher-generated photographic } \\
\text { images }\end{array}$ & $\begin{array}{l}\text { Photographs for analytic as against } \\
\text { illustrative use. Here the visual is a } \\
\text { silent analytical domain and } \\
\text { appearances are rendered as still } \\
\text { images }\end{array}$ & $\begin{array}{l}\text { Sharrock and Anderson (1979) on directional } \\
\text { hospital signs } \\
\text { Ball and Smith (1986) on queuing }\end{array}$ \\
\hline $\begin{array}{l}\text { Researcher-generated real-time } \\
\text { video recordings }\end{array}$ & $\begin{array}{l}\text { Video data produced by the researcher, } \\
\text { lacking a soundtrack, analyzed for } \\
\text { analytical purposes }\end{array}$ & Ryave and Schenkein (1974) on walking \\
\hline $\begin{array}{l}\text { Researcher-generated real-time } \\
\text { audio-video recordings. }\end{array}$ & Moving images with natural sound. & $\begin{array}{l}\text { Goodwin (1994) on professional vision } \\
\text { Heath (1986) and West (1984) on medical } \\
\text { consultations }\end{array}$ \\
\hline $\begin{array}{l}\text { Researcher-generated audio-video } \\
\text { recordings of indigenous uses of } \\
\text { images and video }\end{array}$ & $\begin{array}{l}\text { Real-time researcher-generated } \\
\text { audiovisual data of how professionals } \\
\text { use images and video as part of their } \\
\text { work }\end{array}$ & $\begin{array}{l}\text { Mondada (2003) on how surgeons teach } \\
\text { using video of their surgery } \\
\text { Hindmarsh and Heath (1998) on how video } \\
\text { can be used for the analysis of objects in } \\
\text { action }\end{array}$ \\
\hline
\end{tabular}

Our chapter concentrates on six of the categories identified in Table X.2, beginning with studies adopting ethnographic techniques, where a good eye (and ear) and memory matters more than an effective recording device, to the high-technology end of the spectrum, where visual methods are used to study the activities of those who are themselves reliant upon visual technologies to carry out their working practices. The chapter concludes with a summary of issues and projected future directions for EM-inspired research into the visual.

\section{ETHNOGRAPHIC RESEARCH}

Many early studies in EM used the established methods of ethnographic observationand interviewing. In some of these studies, the visual dimension was submerged in a broader notion of appearances that formed the basis for inferences and action. Bittner's (1967) study of how the police keep the peace in skid row suggested that they make on-the-spot judgments about the likelihood of a situation getting out of 
hand. Cicourel's (1968) study of juvenile justice procedures noted the importance of offenders possessing an appropriately well-demeaned appearance when their cases came up for disposal by the courts. Attention to the visual has alwaysformed a component within EM studies, evident in studies of such diverse phenomena as the visual dimension involved in learning to play jazz piano (Sudnow, 1978, 2001), and working with the visual features of numbers in mathematics (Livingston, 1986).

As Garfinkel's consideration (above) of the case of Helen's practices of scanning her immediate environment demonstrates, there is a form of interpretive work that the normally sighted largely take for granted. In the course of our ordinary affairs we routinely glance at the looks of things we encounter. Especially in public places, glancing is a routinely employed practice of looking. Sudnow reminds us of the range of visual glancing work that members routinely engage in for gleaning relevant information about social contexts while carrying out courses of practical action, such as:

in the co-ordination of automobile or sidewalk pedestrian traffic where single-glanced monitoring of others' actions is an often required procedure, or, in other situations chiefly ceremonial and social, as in the numerous activities where the immediate spontaneous, glance-based recognition of another's moves, categorical status, gestures, etc. is strongly sanctioned and violations sometimes harshly noticed (for example "Hey I was in line here", "Why are you staring" etc.). (1972: 260)

Sudnow's treatment of the glance starts from the premise that the glance is a member's device and not an analytic unit. By so doing, he draws our attention to the practical relevance of time and space for understanding contexts of non-verbal social behavior.

For Sudnow, a single glance in public spaces is often fully adequate to the task of categorizing persons and features of settings while engaging in courses of practical action. He writes: 'for many activities, the glance is the maximally appropriate unit of interpersonal observation' (1972: 260). Sudnow emphasizes the temporal dimension of glances, which can be consequential and accountable in terms of the information acquired and the interactional context. As Sudnow notes: 
That the timing of a glance might be consequential for its informational adequacy may be suspected in the light of the fact that many of the aspects of scenes whose glanced-at "observability" and 'interpretation' seem regularly achieved are aspects that may be regarded as organized as "courses of action", having spatially and temporally extended dimensions. (1972: 261)

Sudnow further explores the informational potential of the glance by comparing it with the still photographic image. Glancing might be thought of as a kind of mobile, embodied camera work, a form of mechanical glancing. But Sudnow insists that this is not a fair analogy. In contrast to glances, still photographic images are records of the 'decisive moment' (Cartier-Bresson's [1952] memorable phrase) in which the image is made, and aided by subjects who may 'pose' for the camera.

EM's concern to analyze the specifics of situated conduct focused on how the looks of things are used by skilled embodied agents working in a material world. One compelling examination of how attention to the looks of things connects looking with subsequent sociological preoccupations with embodiment and materiality is Sudnow's treatment of learning to play improvised jazz piano (Sudnow, 1978, 2001). This is an early EM example of what has come to be known as'self-observation' (Rodriguez and Ryave 2002) or 'self-reflection' (Francis and Hester 2004) in EM . The technique involves the researcher turning ethnographic techniques toward their own actions and experiences.

Learning to play the piano is a practical embodied achievement. It involves acquiring the competence and dexterity to produce recognizable patterns of sound from the work of fingers on the keyboard. Learning to play improvised jazz piano calls for a further competence. As Sudnow put it, 'My hands have come to develop an intimate knowledge of the piano keyboard, ways of exploratory engagement with routings through its spaces, modalities of reaching and articulating, and now I choose places to go in the course of moving from place to place as a handful choosing' (Sudnow, 1978: xiii). Sudnow's analysis of how he learned to play improvised jazz emphasizes learned embodied skills. It was very much a matter of developing particular musical skills in his hands (hence the book's title, Ways of the Hand). The acquisition of these skills often involved scrutinizing the keyboard for solutions to the problem of where the hands are to go next: 
...my looking, an appeal to the keyboard for answers, was party to a theoretic in-course analysis I did over the keyboard's sights, trying to keep the terrain under regard to aid large leaps and get from one path to another, a looking that was altogether frantic, like searching for a parking place in a big hurry. (Sudnow, 2001: 35)

Sudnow takes the reader through the intricacies of notes, chords, timings, pulsings, repetitions, runs, returns, and so forth. These courses of practical action made up the work of playing improvised jazz piano. He used photographs of hand positions on the keyboard and diagrams alongside linguistic descriptions to convey the difficulties and challenges his hands encountered in his efforts to learn to play improvised jazz piano. These images give specific material sense to the written description of the text, showing that which is linguistically described.

In an early paper originally prepared for his class with Goffman at Berkeley, Harvey Sacks (1972) explores aspects of the practical work of the patrolling police officer. Sacks drew upon his ethnographic observations as well as documentary sources such as police training manuals for data. Sacks treated the police as an occupational group licensed to engage in the detailed glancing or observation of people in public spaces. How do the police assess the moral character of persons in public spaces, based only on the looks of things (Sacks, 1972: 280)? The solution 'begins with the fact that persons within society are trained to naively present and naively employ presented appearances as the grounds of treatment of the persons they encounter in public places' (Sacks, 1972: 283). In this paper, Sacks considered how the police on patrol learn to operate with a collection of background relevancies and expectancies for making sense of the behavior of those they routinely encounter. He showed how the police learned to see the appearances of persons and their presented behaviors, when nothing out of the ordinary seemed to be transpiring, as collections of normal appearances. As Sacks informs us about the training of novice police officers:

As he walks through his beat with a mature officer, persons who to him appear legit are cast in terms of the illicit activities in which the latter knows they are engaged. The novice is shown how to see the streets as, so to speak, scenes from pornographic films. (1972: 285) 
The novice is thus taught to look for people who 'don't look like they belong round here,' vehicles parked in places and times that seem 'unusual,' or activities that do not seem to be transpiring in quite the expected pattern. Such sense-making involves what Sacks refers to as an 'incongruity procedure.' It depends upon the acquisition of occupationally specific cultural knowledge by police officers that sets a baseline set of understandings about the normal appearances of persons, districts, activities, and so on. The situated and localized inferential work of the incongruity procedure is not just looking but is thoroughly cultured looking enacted in specific social contexts.

\section{FOUND IMAGES AND DOCUMENTS}

One of EM's interests in images resides in how they are used as documents to facilitate the carrying-out ('accomplishment') of a particular social practice. In this section, we shall consider two studies that focus on the role of existing (or 'found') images in the social practices of (1) finding one's way to a specific destination and (2) reading a mammogram for evidence of possible pathology.

George Psathas (1979) studied the directional maps people draw by hand in order to help guide other persons to a location (usually their home or some other meeting place). Often these maps are sent out with party invitations and are intended to be self-explanatory. Sometimes, however, these maps can be sketched on the spot in the presence of another person to whom directions are being given. Psathas calls these 'occasioned maps' because they are talked about while being drawn, often with questions, answers, and explanations being provided in the course of drawing. Occasioned maps address the co-present person and their particular journey. The analysis provided by Psathas is one example of an ethnomethodological study of a visual object.

Unlike the maps that cartographers draw, the directional map is not a descriptive, objective, all-inclusive map of an area. Rather, it is a map constructed with the very specific purpose of 'showing a way to a particular place.' It is just intended to show someone how to get to a specific destination. Only those roads and landmarks that are 'on the map' are deemed relevant for getting to the destination. Psathas reviewed a number of directional maps and elaborated their features. He showed how streets can be located in 
sequential terms 'as between, across from, before and after, over and under' (Psathas, 1979: 222) other streets and landmarks. The orderly properties of sense-making were established by a careful scrutiny of a sample of directional maps as visual objects used by people in the practical matter of finding their destination.

Found images and documents were the principal source of data for an EM study of the reading of mammograms by radiologists and other medical staff (Slack et al., 2007). The researchers suggested that reading mammograms was best understood as a cultural practice rather than an individual cognitive act. The work of creating mammograms and interpreting them for evidence of pathologies is highly skilled. Slack et al. focused on the 'lived work' involved in reaching an adequate interpretation of what the mammogram set shows about the condition of a woman's breasts. The lived work included practices such as the comparison of a current mammogram set with earlier sets for the same patient, and various techniques to distinguish the artifactual from the actual in the mammogram. In focusing on the mammogram as a central diagnostic document for a community of users, Slack and co-workers drew upon their own observations of how radiologists made decisions. They also interviewed staff about their working practices. By using these methods in combination, they were able to highlight how the mammograms were used and thus show the social dimensions of the looking that led to an appropriate decision by the radiologist.

\section{RESEARCHER-GENERATED PHOTOGRAPHY}

Our next category considers some EM studies that draw upon photographic images as data in order to highlight how features of local social settings are visually conveyed to persons: here, photographs are used to supplement observational research. As 'aids to a sluggish imagination' (Spiegelberg's phrase, quoted by Garfinkel, 1967: 38), photographs provide the researcher with a documentary record of appearances that can be repeatedly viewed and scrutinized for features that may escape the unaided ethnographic eye. This section concentrates on queues and finding one's way using directional signs.

Queues and queuing arrangements are routine features of daily life in many cultures across the world. 
For ethnomethodology, the queue is but one example of 'the witnessed and produced orderliness of practical action' (Livingston, 1987: 13). Queues arise when a desired service or facility is temporarily available to an agent or item requiring access to the service or facility. They are an organizational arrangement for allocating access to the facility or service. Queues frequently occur in public spaces among unacquainted persons. They tend to be relatively short-lived units of social organization that are visually available to viewers who readily recognize what they see. For queues to work as successful social arrangements, members must possess the interpretive capacity to recognize them as visual behavioral patterns. $^{2}$

In a study of a set of still photographic data, we (Ball and Smith, 1986) formulated a typology of queuing arrangements as a preliminary to the analysis of the 'properties of the order of service in queues.' We distinguished 'incarnate' queues that included people and vehicles from queues of 'items,' such as books waiting to be returned to stacks by librarians, exam scripts and essays waiting to be marked by an examiner, and factory products awaiting the next stage of the manufacturing process (Ball and Smith, 1986: 29). The distinguishing characteristic of item queues was that they have no potential for selforganization or regulation. They are ordered and organized by external human agency either directly or indirectly. Incarnate queues-people at bus stops and milk floats at a dairy-were the principal concern of our analysis. As we suggested:

Visual information about persons and objects in the immediate environment plays a major role in all unfocused interaction and queuing is no exception. In this paper we wish to propose a further refinement of this idea. We suggest that the orderliness of queues is primarily dependent upon the interpretive work undertaken by queuers, interpretive work that centers upon the reflexive monitoring of visual information. This feature we shall refer to as the "visual availability" (Sharrock and Anderson, 1979) of queuing's local organization, for queues possess a social organization the elements of which are transparent and available to participants and passers-by alike. In this paper we attempt to specify some of the elements figuring in the queuer's practical reasoning. (1986: 27-28)

We drew attention to the visual dimensions of queuing in part by sharing our data, still photographic 
images, with the reader (see Figure X.1). Queues are particularly photogenic social phenomena, as Garfinkel and Livingston also noted: queuers are 'incessantly engaged with the work of producing the order of service, embodied audio-visual details are their central, substantive, content-specific congregationally relevant business at hand' (2003: 22). In keeping with these emphases, we examined the queue as a unit of social organization. We approached the queue from the vantage of the members who assemble it -'doing queuing'-and also from the more abstract analytic level of the queue as a social system constructed from people's practical actions. The study took into account aspects of queue ecology, the basic and evident visual parameters of queues, such as the practical significance of the height, width, length of queues, and the 'natural boundaries' (Ryave and Schenkein, 1974) of the environment in which the queue was located.

In most everyday examples of queuing arrangements, their practical assembly is informed by the turntaking system of 'first come, first served' (FCFS). As an organizational principle, FCFS is also of relevance in other instances of social organization such as turn-taking in conversations (Sacks et al., 1974; ten Have, 1999; Francis and Hester, 2004). However, the turn-taking system of queues was visually available to other people in the situation. As Garfinkel and Livingston suggested, 'parties to a queue characteristically want the queue to be evident with conveniently assessed displays of its statistics' (2003: 21). Similarly, as Ball and Smith pointed out:

Queues are ... not just visible social phenomena; they display their turn organization in their linear appearance. It is the orderliness of FCFS which the linear appearance of the queue reveals. Ordinal position and thus turn are available to co-present persons in the setting "at a glance." (1986: 35)

\section{Insert Figure}

Figure X.1 (a)-(h) The visual availability of a queue's local organization: 'first come, first served' in action. (C) 1986 Ball and Smith, reproduced with permission from Communication and Cognition, 19(1). Note: queuers are waiting on a sloping bridge.

Using a series of strategically made still photographs as data, our research developed an account of the social process of queuing, showing how queues emerge and dissipate and how movement through queues 
occurs. The methodological significance of our research lies in how our photographic images demonstrate the visual availability of the orderliness of queuing in a manner that can be subjected to scrutiny by analyst and reader alike.

Our queuing study built upon the methodologically innovative work of Sharrock and Anderson (1979), which also used a small collection of still photographs in an investigation of hospital directional signs. In large organizations such as hospitals, finding one's way is assisted by the placement of directional signs within the hospital environment. The patient's general competence with and commonsense practical use of such a system of signs to find their way around is taken for granted. Sharrock and Anderson began by asking, 'Why should two sociologists be interested in some hospital signs, more precisely in five photographs of a dozen or so such signs?' (81). Their answer was:

In our case, the collection is, first, a collection of photographs, of signs, made because we thought that signs were natural things to choose in the context of enquiring into the visual availability of social scenes, for signs are to be looked at. (1979: 83)

Plainly, this returns us to our consideration of the methodological bases of EM research into the visual, and the analytic uses of still photography. For Sharrock and Anderson, systems of directional signs serve the practical purposes of people finding their way within the hospital. But more generally, pictorial and written signs are there for a purpose, and comprise a visually available feature of public and semi-public spaces. Directional signs can be seen individually at a particular site or they can be treated as part of a broader system of related signs. Directional signs in hospital environments are read in ways shaped by practical purposes. People will encounter the signs one at a time and at their normal walking pace. The signs will be sufficiently brief that people will not usually need to pause to read them before continuing on their way. Thus, the signs are read in situ and the reading is governed by a thoroughly practical motive ('How can I get to...?'). In hospitals, directional signs are designed to furnish information and are frequently organized sequentially, so that a sign to 'Physiotherapy' will be followed by further so-named signs until the follower of the sign has arrived at the Physiotherapy Department. In this respect, they share common 
characteristics with other forms of directional signs such as road signs that provide directions and the road number: for example, M1, London, The South (Ball, 2005). As Sharrock and Anderson put the matter:

When we think of people using signs it becomes obvious that the use they make of them is practical. They are not interested in the meaning of the sign but are interested in using the sign for some purpose. They are not interested in what signs in general mean, but in the use they can make of This sign, Here and Now. Their reasoning is not theoretical and general but practical, particularized and in context. (1979: 81)

But these readings of directional signs were not haphazard or idiosyncratic. Rather, readers of these signs (and those who design signage for hospitals, road networks and the like) employed methodical practices of sense-making that carefully distinguish the location, juxtaposition, and sequencing of signs.

\section{RESEARCHER-GENERATED REAL-TIME VIDEO}

Early ethnomethodology also used videotaped data to investigate further features of the orderliness of actions in public places. In this section we commence with a review of a classic study on the 'art' of walking by A. Lincoln Ryave and James N. Schenkein (1974). What is methodologically significant about this paper is that it is based upon two 8-minute segments of videotape of a public pavement mainly used by students. The researchers 'filmed at a time when students are routinely negotiating their way from class to class' (Ryave and Schenkein, 1974: 265). As the video lacked a soundtrack, it isolated the visual component of behaving as a pedestrian in public settings (Ryave and Schenkein, 1974; also see Lee and Watson, 1992).

The videotaped students were characterized as 'doing walking,' the verb employed in order to emphasize the active, produced feature of this routine and mundane activity. The commonplace action of walking was analyzed as an ongoing situated accomplishment in terms of its production and recognition. Walkers navigated their way through environments that are shaped and structured by 'natural boundaries,' such as walls, curbs, parked vehicles, posts, and other items of street furniture (Ryave and Schenkein, 1974: 266). Ryave and Schenkein explored aspects of how people move their way through public spaces, while encountering what they refer to as a 'navigational problem': how to avoid collision with others. Once again, they addressed aspects of the production and recognition of normal everyday 
orderly behavior in public spaces by considering how individuals and collections of people can come to be seen as moving obstacles. They distinguished between people walking together as a group, which Goffman (1963) has referred to as a 'with,' from people walking alone, who were careful not to 'walk through' people walking together.

It may be instructive to compare Ryave and Schenkein's study with a more recent EM treatment of walking in public spaces. Hester and Francis (2003) explored aspects of the visual order of walking by in part becoming what Sacks had referred to as a self-commentating machine. Here the researcher, when walking to a supermarket, narrates into an audio recording machine a description of their actions, for all practical 'analytic' purposes. One consequence of this methodological strategy is that the visual is transformed into the verbal, a common device in a 'discipline of words' (Mead, 1975; Signorelli, 1984).

The development of the visual analysis of methodical practices of sense-making in public places has been furthered by Watson's (2005) adaptation of membership categorization analysis to the phenomenon of 'flow files.' Using naturalistic observation as well as videotaped data, Watson identified one form of locomotion through public space: the flow file. This form of locomotion is found where a group of pedestrians make their way toward a destination, one following the next, at a regular pace. There is a moral order to the flow file. The first pedestrian assumes the 'leader' category, forging a path through the sometimes-crowded public spaces. The leader has category-bound obligations about the direction and pace of the file, ensuring it travels at a rate that all file members can maintain. Flow files, Watson concludes, 'are at once locally situated, sequential-categorial phenomena' (Watson, 2005: 221). He further suggests that 'A huge variety of membership categories can be seen to be in play in urban public spaces. In this sense, it is misleading to see those spaces as a "world of strangers"' (Watson, 2005: 222).

A conspicuous methodological advantage of the use of videotaped data is that it offers the analyst the permanent possibility of reviewing the particulars of the conduct it records. Re-inspection and re-analysis of the visual data is facilitated by the playback opportunities allowed by the technology. In addition, recorded visual data have the potential to be shared with the reader/viewer in an open manner that lays 
bare the processes of interpretation that are so often simply taken on trust in standard forms of ethnographic research. This methodological strategy was inspired by the use by conversation analysts of audiotaped data. ${ }^{3}$ However, inspection of the publication of both Ryave and Schenkein's study and Watson's study shows that no extracts from their visual data were presented to readers. In this respect, their research resembles the observation-based work of Sudnow and Sacks with the attendant concerns about ethnographic validity (the empirical foundation of the analysis was not presented). However, this difficulty might be better regarded as a presentational and publishing issue than as a methodological or analytical one. Often, simply the economics of academic publishing create the constraint.

\section{RESEARCHER-GENERATED REAL-TIME AUDIO AND VIDEO}

We commence this section with a study by Garfinkel et al. (1981) that properly speaking belongs under a different heading, that of audiotaped recordings. Our decision to stretch our headings is motivated by the importance of the approaches that follow from this study. Garfinkel et al. has been an important source in the area of science studies and has contributed to further development of the study of 'lived work' in various other areas of EM research.

Although specialized bodies of knowledge and highly technical procedures are implicated in scientific investigation and discovery, from EM's perspective the same orders of practical reasoning and communicative skills are found as are involved in walking together or finding one's way through hospital corridors. EM's emphasis on science as a form of situated social activity was not intended to downgrade or undermine scientific work. Rather, EM studies of science sought to preserve and analyze the actual practices of scientific work, while also noting how these practices depended upon broader forms of commonsense cultural knowledge and competence in conjunction with the more obvious esoteric forms of knowledge and practice conventionally associated with science as an activity.

Some of these emphases can be found in the analysis of the practical work of discovery in science reported in Harold Garfinkel, Michael Lynch, and Eric Livingston's 1981 study of astronomical discovery. Garfinkel et al. were given access to a recording of a group of scientists who taped their talk as they 
worked at the Steward Observatory when discovering an optical pulsar on the night of 16 January 1969. Garfinkel et al. used the data recorded on the tape to find significant insights into the practical organization of the work of discovery, including the visual analysis of scientific data. They sought to understand the nature of scientific discovery as a form of situated social action that preserves the 'local historicity' of the discovery: that is, the scientists, when they reported for work at the Steward Observatory on the 16 January, did not know at the outset that they would be discovering the first optical pulsar. So, Garfinkel et al. paid close attention to parts of the talk such as the following:

Disney: (we've got a little bit of shape now). (0.4)

McCallister: We::Il, (1.0)

McCallister: (it's) about like I saw in that sky: over there, $t^{\prime}$ tell you the truth. (0.5)

McCallister: The's a nice di(hh)p on the (hh) si(hh) de of that sky. (0.5)

McCallister: I'm gonna turn this thing down. (2.5) ((machine sound-probably gain switch))

Disney: We've got a bleeding pulse here (2.0)

Cocke: He::y! (4.5)

Cocke: Wo:::w! (1.2)

Cocke: You don't suppose that's reyally it, do you? (2.0)

Cocke: Ca::n't be:.

Disney: It's right bang in the middle of the period. (look), I mean right bang in the middle of the (sca::le).

Disney: It reyally looks something (from here) at the moment. (to me) (0.8)

Cocke: Hmm:! (3.0)

Disney: (an') its growing too. (hey) (1.0)

Disney: It's growing up the side a bit too. (Garfinkel et al., 1981: 149). 
Much of the practice of scientific work reported here was concerned with rendering visible the invisible. In the instance above, the scientists worked with images in the form of electronic data displays. Their talk concerned their practices as astronomers as they worked with and reacted to data that came in live from a radio telescope, working in real time, moment by moment, and discovering that the data revealed evidence of an optical pulsar. This was the work of scientific discovery: phenomena that are invisible with the naked eye were transformed into visible traces.

Even a cursory examination of this corpus of data showed that the work of science, in common with many other practical activities for normally sighted people, was embedded in the visual domain. Scientists have been characterized as engaged in a process of 'seeing the physics' (Lynch and Edgerton, 1988: 213). This involved digital image techniques that used pictorial and graphical electronic displays to show abstract measures in a more palpable, visual format. The use of an observational terminology was reflected in the talk of the scientists as they worked. Visual matters were oriented to in and through talk. Within the 15 units of talk between Disney, McCallister, and Cocke, mention was made of: visual 'shapes,' seeing things ('I saw in that sky over there'), turning down a machine to obtain a better image, the initial recognition of a 'pulse' and the description of its observed growth. The talk progressed from Disney's utterance, 'we've got a little bit of shape now'-a comment referring to an emerging image of an astronomical phenomenon - to Disney's comment, 'It's growing up the side a bit too.' All this talk was derived from just one 'observational run' of a number carried out that night. Successive subsequent runs were new and different from previous ones but were designed to furnish further evidence of the presence of the optical pulsar. Of course, all this work depended upon knowledge of the scientific specialism shared by the scientists working that night in the observatory. The idea that shared specialist knowledge provides the basis for specialized ways of looking takes us toward Charles Goodwin's (1994) influential concept of 'professional vision.'

The notion of 'professional vision' was designed to show how all occupational specialists work within the accepted ways of seeing licensed by their professional domain (Goodwin, 1994). Goodwin examined how field archaeologists and lawyers draw upon occupationally specific ways of seeing in order to 
accomplish their professional work. Goodwin notes how:

Discursive practices are used by members of a profession to shape events in the domains subject to their professional scrutiny. The shaping process creates the objects of knowledge that become the insignia of a profession's craft: the theories, artifacts, and bodies of expertise that distinguish it from other professions.

He examines how a profession's craft is embodied in its routine practices with especial reference to the visual dimensions of that work. To investigate the professional vision of archaeologists and lawyers, Goodwin principally drew upon videotaped data of archaeological field schools in Argentina and the USA, and videotapes of the first Rodney King trial. Videotape preserved both participants' talk and body movements, rendering them amenable to repeated, detailed scrutiny. Recorded talk in particular was amenable to transcription (CA systems of notation have become standard in EM). Goodwin's analysis focused upon three practices in each of his two settings: (1) the 'coding schemes' used to transform features of a setting into objects of profession-relevant discourse; (2) the 'highlighting' practices used to mark as significant certain specific phenomena in the setting; and (3) the production and articulation of graphic representations.

In the case of archaeological fieldwork, Goodwin shows how students are taught to use Munsell color charts as coding schemes to systematically identify the color of the dirt they are digging through. Highlighting in the field is often done by the trowel work of archaeologists, who use their trowels to mark lines in the ground to identify features of interest such as molds of posts that may once have supported a house. Archaeologists also produce sketches, maps, and diagrams that are graphic material representations of features of archaeological relevance. Their production is a collaborative and sometimes contested endeavor.

The element of contestation was much more pronounced in lawyers' work. The novel move Goodwin then made was to suggest that the same framework of coding, highlighting, and graphic representation can be used to illuminate the trial of Rodney King, the African-American motorist filmed by an amateur 
photographer being violently beaten by four Los Angeles police officers in 1991. Goodwin provided a detailed analysis of how King's conduct was coded by the officers' defense lawyers as aggressive, his body movements minutely highlighted and pointed to as indicative of incipient violence, so that the amateur video of the beating came to be seen as a representation of 'police craft-work' in dealing with an 'aggressive offender.' In this way three of the officers were acquitted of wrongdoing at the first trial. ${ }^{4}$

Goodwin developed his analysis of professional vision with close attention to stills and videos of archaeological fieldwork and the trial as shown on TV. He made the now-standard EM observation that the use of videotaped data renders his analysis open to ready checking and challenge by other researchers. In conclusion, Goodwin (1994: 628) emphasized that professional vision is not merely a frame of mind or mental set. Professional vision is made manifest through people's embodied, situated practices, ${ }^{5}$ and it is through these practices that something as apparently subjective as processes of learning, whether in archaeology field school or the courtroom. He also suggested that professional vision could be seen as part of the workings of professional power, especially if power was understood in the Foucauldian sense of discourses that articulated the conditions of rationality in a society and the kinds of talk that can and cannot be heard. In this way, Goodwin points to some ways in which EM can deepen the understandings provided by other social scientific perspectives.

Goodwin (1994) has been especially influential is shaping some directions taken by visual ethnomethodological research. It is the single most-cited article published in the prestigious journal American Anthropologist (https://anthrosource.onlinelibrary.wiley.com/journal/15481433/).

A series of related articles by Goodwin extend the concept of professional vision. These include studies of how airport workers see planes and how different scientific specialties make sense of the evidence collected by an oceanography research vessel (Goodwin and Goodwin 1996; Goodwin 1997; Goodwin 1995). To briefly review the airport study: this considers the perspectives of different categories of worker approached not as a set of mental constructs enclosed within the skull but rather as features of practical reasoning analyzeable in the talk, tools and documents routinely used in dealing with the flow of work at 
the airport. Talk, tools and documents and the perspectives they support are embedded in courses of action making up staff's work tasks. A key coordinating role was played by the Ops Room. This may look like a grand Panopticon, more all-seeing than anything Jeremy Bentham could have envisaged. However, the Goodwins emphasise that there is "no single master view". Instead, Ops Room staff must bring together multiple perspectives using disparate tools to solve the problem at hand and this occurs as a course of action unfolding in time. No master view emerges or can be distilled from such processes. The study shows how an ethnomethodological approach treats perspectives as more than matters of representation. Perspectives are grounded in participation in courses of action.

The concept of professional vision has proved immensely influential in a range of work-related settings. It has obvious relevance in high tech areas of work, such as Vertesi's (2012) study of the robotic 'eyes' of the Mars Rover that shows how the professional vision of the Rover team is founded in embodied practices of talk, gesture and visualization. For example, the Rover's image work is planned by collaboration between team members who will use devices like using their own limbs and torso to visualize the positioning of the Rover's cameras to carry out a particular task. But it has also proved helpful in understanding more traditional settings. Here Grasseni's (2004) study of a community in a mountainous area of northern Italy can be noted. It uses the notion of professional vision to discover the cultural intricacies of the features of a 'good cow' as understood by community members. Forms of professional vision may be present everywhere where there is work.

Technological developments have simplified the making of audio and video recordings of ordinary human actions and ways of seeing can be accessed for analysis. Ethnomethodologists have long been aware of the potential of these developments for their explorations of the production and recognition of ordinary actions. One early significant contribution was Christian Heath's (1986) study of medical consultations in general practice in the United Kingdom (UK). Drawing upon a substantial corpus of videotaped data, Heath (1986: 3) was especially interested in the visual aspects of conduct during the consultation and their relation to the vocal stream. While vocal elements of the consultation could be 
graphically rendered by normal CA transcription conventions, visual elements proved more difficult to transcribe (an oft-noted difficulty that Heath informs us first attracted comment in 1806). Heath devised a system of notation to represent aspects of actions such as gaze direction, turning away from a participant, turning toward another participant, and raising of the hands. While these symbols could be integrated into standard CA-type transcripts, the system seemed not quite as robust as CA's orthography. Heath often needed to make supplemental notations in the form of his brief written descriptions of the activities occurring. ${ }^{6}$

Conversation analysts have shown the many ways in which talk is responsive to its sequential organization. How turns at talking are taken is one of the fundamental ways in which conversation is organized. CA has identified the organization and workings of adjacency pair structures, structures of repair and closing and the like. Heath proposed that visual actions are also structured on a stepby-step basis that is locally organized and sensitive to the immediate situation:

...in exploring the action(s) a movement accomplishes, it is helpful to examine how it is dealt with both during and following its production and to consider "why this now": How does the person's conduct assist with or deal with the circumstances at hand? Certain components of a body movement may implicate action by others whilst forming part of an overall activity accomplished with talk. (1986: 17)

These analytic and methodological considerations equipped Heath to analyze key aspects of the medical consultation: how looking is used to initiate the consultation; how vocal and visual actions are coordinated to maintain involvement in the consultation; the various forms of participation possible in the consultation; the management of the physical examination; and the organization of leave-taking at the end of the consultation. $^{7}$

Christian Heath subsequently played an important role in for the development of multimodal methods by EM researchers, whose work has been facilitated by the miniaturization of digital video that has permitted relatively inconspicuous camera placement in settings that would not have been practical using older techniques of analogue filmmaking. Haddington and Keisanen (2009) extend Psathas' research into 
directional maps by examining wayfinding en route to a destination by car. Using audio-visual recording devices placed inside cars, they show how drivers and passengers draw upon a range of linguistic, material, embodied and sensory resources to make sense of situations encountered during movement on a car journey. These resources are drawn upon to meet the rapidly changing interactional contingencies of car travel where the here and now may have only a few moments' duration. Like Psathas, they employ numerous illustrative sketches as explanatory devices. 
Kuzuoka et al's (2008) study of sociable robots examined how they could be programmed to use pauses and restarts in order to attract the attention of humans and gain the floor. Using multimodal methods in an experimental study they showed CA findings about pauses and restarts could be applied to redirect the attention of humans toward the robot and its instructions about how to interact with a museum exhibit. The same research group (Luff et al., 2011) also showed the importance of gathering videotaped data in order to explore the interrelations of gaze, pointing and talk between participants interacting in a new media space.

Videotaped data has also proved useful in studying ordinary actions around consumption. For example, in a study of negotiations occurring during admission to an art gallery (Llewellyn, 2015) visitors were offered the possibility of paying a little bit more on the standard admissions price in order to attract a larger donation to the gallery from the government. While the main part of the analysis used CA notions such as preference organization to focus upon the workings of yes/no responses, the videotaped data unexpectedly also revealed the use of blocking and chopping hand gestures to decisively refuse invitations to donate. Such gestures tend to be intricately coordinated with the verbal stream of human conduct, something that videotape opens to analysis. Similarly adventitious findings were generated about the interactional basis of economic activities in Brown and Laurier's (2014) study of discussions about the purchase of a mountain bike between two friends in a car share commute. This underlines a claim that Sacks (1992) made long ago that no feature of interaction should be discounted in the naturalistic study of human action - there is 'order at all points'. Videotaped data as part of a multimodal methodology offer powerful technological assistance towards the realization of that aim.

\section{RESEARCHER-GENERATED AUDIOVIDEO RECORDINGS OF INDIGENOUS USES OF IMAGES AND VIDEO}

The influence of CA approaches is conspicuous in studies of new media technologies that themselves adopt multimodal methodologies. The advent of small portable video cameras that can detect the sounds and 
visible features within range has prompted a range of innovative uses by EM researchers. In addition, the contemporary world is becoming an increasingly screen-mediated place. Indeed, the increasing omnipresence of screens supported by digital technologies has led some researchers to identify a "synthetic situation" (Knorr Cetina, 2009) in which the body-to-body reference point of Goffman's (1983) interaction order is augmented or replaced by the body-to-screen dimension. These developments have been reflected in a range of EM studies. Notable in this regard is Lorenza Mondada's (2003) study of the use of video technologies in medical contexts. Mondada's research was particularly striking because of its central focus upon a range of visual practices. She examined a surgical procedure in which endoscopic cameras were introduced into the patient's body (along with other instruments) by a minimally invasive surgical technique (laparoscopy). The endoscope facilitated an internal view that enabled the surgeons to see their work site within the patient's body on a nearby visual monitor in the operating theater. It was a form of surgery by 'remote control.' The surgeon operated by reference to endoscopic images of locations within the patient's body that were displayed on a visual monitor.

As Mondada informs us:

$$
\begin{aligned}
& \text { Surgeons operate on patients not by looking at the patient's body but by viewing video monitors where } \\
& \text { the images produced by an endoscopic camera navigating into the body are displayed. This technique } \\
& \text { foregrounds the visual skill of the surgeon. It involves work site specific ways of seeing and producing new } \\
& \text { images of the body, characterized by small-scale details, two-dimensional anatomical space and magnified } \\
& \text { particularities made available by particular optical devices. (2003:58) }
\end{aligned}
$$

As if this visual environment were not complex enough, there was another layer of intricacy to Mondada's data. The surgical operation was simultaneously a site of pedagogic activity. While the surgical team carried out the complex tasks of surgery via laparoscopic technology, their surgical activities were recorded simultaneously on video and relayed in real time for an audience of trainee surgeons who were outside the operating theater. Also simultaneously, the surgery was 'broadcast' via a video conference connection to an external expert on another continent who offered advice online. So there were three categories of participant in the event: the operating team, the trainees, and the external expert. Each 
category reflected the three kinds of activity that were going on simultaneously-an operation; a demonstration of a surgical technique; and an occasion for expert counseling and learning about that technique. Mondada's analysis showed how the participants orient to their respective participation statuses in this 'telemedical event,' and provided an examination of the workings of professional vision in action.

In the published paper, Mondada presented the reader with three types of images: (1) from inside the patient's body, generated by the endoscopic camera and shown on the operating theater's visual monitor (the endoscopic view); (2) images of the surgical team working on the surface of the patient's abdomen with their hands when inserting and extracting surgical implements (the external view); and finally (3) an image of the surgical team who are making reference to the visual monitor (the researcher's view). Mondada's analysis of the practices of visualization employed on this occasion concentrated on the details of switching between endoscopic to external views; the discussion of the endoscope's optics; and the various, fundamentally collaborative, practices of looking, pointing, and showing in the course of operation. With reference to transcribed data and still images drawn from the video materials, Mondada explicated how 'Surgeons display their attention toward the ways in which their action is being recorded and viewed online by the audience. They accomplish their action in such a way that it is recipient designed, visible and accountable for both the audience and the expert' (Mondada, 2003: 58).

Mondada's analyses, like many others in the tradition now known as 'workplace studies' (Heath et al., 2000; Heath and Button 2002; Luff et al., 2000), 'consider the ways in which the visual, the vocal, and the material, feature with talk, in the production and coordination of organizational conduct' (Heath et al., 2000: 314). While the technology made it possible to repeatedly scrutinize the details of social practices investigated by this research tradition, it is clear that without ethnomethodology there would not have been either the analytical motivation or the theoretical justification for the initiation of such studies.

\section{CONCLUSION}

Multimodal video analyses inspired by CA might seem to be the new orthodoxy that is EM's major current 
contribution to visual studies. Certainly, there is a growing body of empirical research successfully applying these methods to ever-widening topics of investigation. But there is also a range of diversity and debate that continues to animate EM inquiry. Broadly, this can be characterized as a tension between formalizing and phenomenological impulses in EM, a tension evident in Garfinkel's original writings. CA-inspired multimodal analysis represents the formalizing impulse. But the same video methods can also be used to develop very different kinds of EM analysis. For example, the analysis can be oriented towards the the organization of particularities to show how social actions are emergent from the concerted activities of members of society. Thus multimodal methods are used in Sharrock and Greiffenhagen's (2017) study of pairs of secondary school students using computer images of the play to construct storyboards illustrating significant themes from Shakespeare's Macbeth. Yet Sharrock and Greiffenhagen use their video recorded data of the students' work to show how the emergent phenomenon of collaborative class learning is produced through such activities. Another interesting development on the phenomenological side is Sormani's (2016) proposal for 'practice-based video' as an alternative to multimodal video analysis. The latter extends CA's preoccupation with the 'why this now?' question (for example, for turns at talk) to include visual and gestural matters. What is omitted, according to Sormani is the 'technical intelligibility' (2016: 108) of any practice, an intelligibility that can only be grasped when the analyst him/herself learns to enact the practice. Sormani's proposal builds on Garfinkel's (1996) 'unique adequacy' requirement, namely that researchers acquire the skills and competences evident in the phenomena they investigate. The more general issues at stake have been the subject of recent heated debate: see the special issues of Discourse Studies in 2016 (volume 18[5]) and 2018 (volume 20[1]) devoted to the epistemics of Epistemics'.

Our discussion in this chapter has been constructed so as to show the increasingly analytic uses of visual data employed by EM. It introduced Garfinkel's classic formulations of EM and traced their translation into a program for research that accords significance to the visual dimension of social life. While we have resisted offering a presentist history of EM's interest in the visual, we have provided grounds for reading history that shows some evidence of methodological development and cumulation as well as indicating 
some of the grounds for debate and disagreement in the field.

We can trace a development in EM from a broad ethnographic observation-based interest in the visual in the 1960s giving way to the analysis of still images in the 1970s and beyond, before leading to current interests in a range of visualization practices routinely employed in workplace activities. It would be easy to introduce an element of technological determinism into our account. Before the advent of portable video in the 1980s, filmmaking equipment could be bulky, intrusive, and require extensive specialist training for its use. ${ }^{8}$ EM studies, like the social sciences more broadly, have benefited from advances in digital technologies that have made the recording and analysis of visual data more straightforward technically, less obtrusive, and less costly than was known by previous generations of film and video users. In our view, these technological developments simply supplied a resource that served to articulate EM's existing analytical and methodological concerns - the technology has not been a driver in any stronger sense.

This is not to deny the very real practical challenges and opportunities for EM analysis afforded by the use of new technologies. Heath and Hindmarsh (2002) have provided a helpful introduction to the mechanics of data collection and analysis for EM studies of situated conduct. A more detailed guidebook to the practical, theoretical and methodological issues of working in this tradition can be found in Heath et al. (2010). Discussions of the many opportunities offered to students by EM ways of approaching visual data are offered in Emmison et al, (2013) and ten Have (2003). These publications offer accessible introductions that may help to build a bridge to the interests of mainstream practitioners of visual studies.

Issues of representation characteristic of visual studies more broadly also figure in EM studies. Every camera angle implies others not taken. Some of these issues are practical. For example, Hindmarsh and Pilnick's (2007) study of the work of surgical anesthesia described how the camera was positioned so as to capture the surgical procedure in a manner that did not require frequent altering of the position or focus of the camera during filming. The researchers were present during the filming, and their presence was often commented upon (then to be ignored as the procedure commenced). Clearly, different settings will require different decisions of this order. Overall, the primary aim has to be to secure a good record of the 
actions in question. Other issues of representation have taken a more political character. As Goodwin pointed out, 'any camera position constitutes a theory about what is relevant within a scene, one that will have enormous consequences for what can be seen in it later, and what forms of subsequent analysis are possible' (1994: 607).

In addition, presentational concerns need to be noted. As we know from watching and listening to seminar talks, Mondada's research can be more effectively conveyed in a face-to-face setting using a presentational program (such as PowerPoint ${ }^{\oplus}$ ) than by reading the printed page and looking at the images contained in a journal article. For example, Mondada's seminar presentations used split-screen techniques that allowed viewers to see simultaneously what was captured by the surgeons' and researcher's video cameras in real time. Such presentational issues remind us of Margaret Mead's (1975) famous query about the role of images in disciplines of words. They highlight the logocentric character of the traditional academic format of the book and the article. New digital technologies offer opportunities to present academic work in durable form beyond the printed page (see Mannay, 20XX (this volume)).

Questions of image ethics also arise. The special ethical difficulties faced by visual researchers center upon data anonymization. Ethnomethodological researchers continue to be committed to recording and analyzing the details of human conduct 'naturalistically': that is, as it naturally occurs in actual social settings. This creates some obvious difficulties. The storing of images of identifiable individuals held electronically for research purposes is subject to legal restrictions, such as the Data Protection Act (1998) in the UK. In addition, in sociology and neighboring disciplines there are codes of professional conduct that demand that researchers respect the anonymity and privacy of research participants. Frequently, in the images and recordings used in EM research, participants may be readily identifiable by their physical appearance, dress, and voice.

One early solution addressing these ethical sensitivities was Heath's (1986: xiv) use of drawings of medical consultations based on stills made from the video, rather than reproducing the stills themselves. Additionally, Heath (1986: 178, note 22) suggested that the drawings on occasion could offer a clearer 
representation of phenomena of interest than do photographs (Haddington and Keisanen 2009 offer another example of this technique). Interestingly, line drawing can now be generated automatically (see Heath et al., 2010:126). Another solution is to blur the person's face in the image by use of a pixelation technique (see, for example, its use by Hindmarsh and Pilnick, 2007). The pixilation technique can also be used on video images. While this technique can lend a certain strangeness to the resulting images, it is effective in reducing the general identifiability of a person's face, though of course pixilation is not entirely successful at disguising the individual from those who may be able to pick up on other visual clues to personal identity, such as the location of the research. Whether EM analysis requires such 'blanket anonymization' practices in every case is a question that can only be addressed when wider methodological and substantive issues called for by the research design are taken into account (see Clark, 2006; Clark, 20XX (this volume)).

Photography has long been lauded in social scientific circles for its capacity to record the concrete and the particular. EM has long sought to reorient sociology away from generalized or ideal-typical versions of social life toward the study of actual instances in real settings. There is an elective affinity between EM and photography's unique capacity to record the particulars of appearances. The vast impetus given to visual studies and visual sociology by digital technologies is likely to continue. These technologies have functioned as an important methodological resource for EM inquiry, allowing researchers access to analyze the intricacies of human conduct. However, these same digital technologies, insofar as they involve image work and practices of visualization, are increasingly a part of social life and especially occupational life, as the workplace studies tradition attests. Here the analytic focus is directed toward 'working practice, part of which involves those observed, rather than the researchers, using images' (Banks, 2007: 49) ${ }^{9}$ - using images to monitor air traffic in a control room, scrutinize public space on a CCTV screen, interpret videotaped evidence in court, read and act upon financial news displays in a trader's office, and the like.

These studies are consistent with contemporary social theory's preoccupations with materiality and embodiment and indicate areas where EM continues to make a distinctive contribution (see Goodwin, 
2001). Workplace studies offer a close empirical approach to how people use and interact with objects and technologies in their daily lives. At the same time, the focus on actual instances of embodied skill suggests a fruitful way of developing empirical studies of Mauss's (1973; original 1934) key concept of body techniques. Visually oriented EM studies look set to continue to illuminate the intricacies of situated conduct in a material world.

\section{NOTES}

1 Recalling his many discussions with Garfinkel, David Sudnow remembered how 'he pushed me at every point to go for the detailed looks of things' (Sudnow, 1978: viii).

2 Sharrock and Coulter (2003) present a philosophically detailed account of some fundamentals of pattern recognition within visual systems in daily life through their examination of the 'projection problem.'

3 Some of the early transcripts worked on by Sacks and his collaborators were in fact abstracted from video recordings (Mondada, 2008: 2). Similarly, Goodwin's (1981) early attempt to extend conversation analysis to include gaze was based on audiovisual recordings.

4 At the later Federal trial two officers were found guilty.

5 Goodwin (1995) extends his analysis to the biologists, geochemists, and physical oceanographers working on a research ship investigating the composition of water around the mouth of the Amazon. Goodwin examined the multiple professional visions at work on board the ship, while also acknowledging the role of 'seeing in common' (Goodwin, 1995: 262-264).

6 There seems to be a trade-off between the comprehensiveness of a transcription and its ready intelligibility. Schegloff (2000) refers to this as the issue of 'granularity'-How much detail is required in a specific transcript?

7 Later work by Heath and his colleagues has adopted this same approach to the ways in which talk and conduct feature in everyday work contexts. The tradition of 'workplace studies' (Heath et al., 2000; see also Heath and Button, 2002) has examined the situated use of new technologies in settings such as control centers, financial institutions, operating theaters, the construction industry, and the mass media. 
8 In anthropology a tradition of ethnographic film developed throughout the course of the second half of the twentieth century (Ball and Smith, 2001). It often involved collaboration between a filmmaker and an anthropologist.

9 Of course images are also used by the researcher. Banks draws our attention to the increasingly characteristic EM concern with practices of visualization.

\section{REFERENCES}

Baccus, Melinda (1986) 'Sociological indication and the visibility criterion of real world social theorizing', in $\mathrm{H}$. Garfinkel (ed.), Ethnomethodological Studies of Work. London: Routledge and Kegan Paul.

Ball, Michael S. (2005) 'Working with images in daily life and police practice: An assessment of the documentary tradition', Qualitative Research, 5(4): 499-521.

Ball, Michael S. and Smith, Gregory W. H. (1986) 'The visual availability of queueing's local organization', Communication and Cognition, 19(1): 27-58.

Ball, Michael S. and Smith, Gregory W. H. (1992) Analyzing Visual Data. Newbury Park, CA: Sage Publications.

Ball, Michael S. and Smith, Gregory W. H. (2001) 'Technologies of realism? Ethnographic uses of photography and film', in P. A. Atkinson, A. Coffey, S. Delamont, L. H. Lofland and J. Lofland (eds.), Handbook of Ethnography. London: Sage Publications. pp. 302-319.

Banks, Marcus (2007) Using Visual Data in Qualitative Research. London: Sage Publications. Barthes, Roland (1977) Image-Music-Text. Glasgow: Fontana.

Bittner, Egon (1967) 'The police on skid-row: A study of peace keeping', American Sociological Review, 32(5): 699-715.

Brown, Barry and Laurier, Eric (2014) 'Word of mouth: Products, conversations and consumption', Consumption Markets \& Culture, 17(1) 29-49. DOI:10.1080/10253866.2012.675827

Cartier-Bresson, Henri (1952) The Decisive Moment. New York: Simon and Schuster. 
Chalfen, Richard (1987) Snapshot Versions of Life. Bowling Green, OH: Bowling Green State University Popular Press.

Cicourel, Aaron V. (1968) The Social Organization of Juvenile Justice. New York: Wiley.

Clark, Andrew (2006) Anonymising Research Data. ESRC National Centre for Research Methods Working Paper 07/06. $\quad$ [Online]. Available from: http://www. ncrm.ac.uk/research/outputs/publications/WorkingPapers/2006/0706_anonymising_research_data.pdf [Accessed 20 September 2010].

Clark, Andrew (20XX) 'Visual ethics beyond the crossroads', in L. Pauwels and D. Mannay (eds.), The Sage Handbook of Visual Methods. (2nd Ed) London: Sage. pp. xx-xx.

Doane, Mary Anne (1991) Femme Fatales: Feminism, Film Theory, Psychoanalysis. London: Routledge.

Emmison, Michael,Smith, Philip and Mayall, Margery (2013) Researching the Visual. Second edition. London: Sage Publications.

Francis, David and Hester, Stephen (2004) An Invitation to Ethnomethodology. London: Sage Publications.

Garfinkel, Harold (1967) Studies in Ethnomethodology. Englewood Cliffs, NJ: Prentice Hall.

Garfinkel, Harold (1988) 'Evidence for locally produced, naturally accountable phenomena of order*, logic, reason, meaning, method, etc. in and as of the essential quiddity of immortal ordinary society (I of IV): An announcement of studies', Sociological Theory, 6(1): 103-109.

Garfinkel, Harold (2002) Ethnomethodology's Program: Working Out Durkheim's Aphorism, edited and introduced by A. W. Rawls. Lanham, MD: Rowman and Littlefield.

Garfinkel, Harold (2006) Seeing Sociologically: The Routine Grounds of Social Action, edited and introduced by A. W. Rawls. Boulder, CO: Paradigm.

Garfinkel, Harold and Livingston, Eric (2003) 'Phenomenal field properties of order in formatted queues and their neglected standing in the current situation of enquiry', Visual Studies, 18(1): 21-28. 
Garfinkel, Harold, Lynch, Michael and Livingston, Eric (1981) 'The work of a discovering science construed with materials from the optically discovered pulsar', Philosophy of the Social Sciences, 11: 131-158.

Goffman, Erving (1963) Behavior in Public Places: Notes on the Social Organization of Gatherings. New York: The Free Press.

Goffman, Erving (1979) Gender Advertisements. New York: Harper and Row.

Goffman, Erving (1983) 'The interaction order', American Sociological Review, 48(1): 1-17.

Goodwin, Charles (1981) Conversational Organization: Interaction between Hearers and Speakers. New York: Academic Press.

Goodwin, Charles (1994) 'Professional vision', American Anthropologist, 96(3): 606-633.

Goodwin, Charles (1995) 'Seeing in depth', Social Studies of Science, 25: 237-274.

Goodwin, Charles (1996) Transparent vision', in E. A. Ochs, E. A. Schegloff and S. Thompson (eds.) Interaction and Grammar. Cambridge: Cambridge University Press, 370-404.

Goodwin, Charles (2001) 'Practices of seeing visual analysis: An ethnomethodological approach', in T. van Leeuwen and C. Jewitt (eds.), Handbook of Visual Analysis. London: Sage Publications. pp. 157-182.

Goodwin, Charles and Goodwin, Marjorie (1996) 'Seeing as situated activity: Formulating Planes', in Y Engeström and D. Middleton (eds.) Cognition and Communication at Work. Cambridge: Cambridge University Press.

Grasseni, Cristina (2004) 'Video and ethnographic knowledge: Skilled vision in the practice of breeding', in S. Pink, L. Kürtti, and A. I. Afonso, (eds.) Working Images: Video Research and Representation in Ethnography. London: Routledge, 15-30.

Haddington, Pentti and Keisanen, Tiina (2009) 'Location, mobility and the body as resources in selecting a route', Journal of Pragmatics, 41(10), 1938-1961.

Heath, Christian (1986) Body Movement and Speech in Medical Interaction. Cambridge, UK: Cambridge University Press. 
Heath, Christian and Button, Graeme (2002) 'Editorial introduction: Special issue on workplace studies' British Journal of Sociology, 52(2):157-161.

Heath, Christian and Hindmarsh, Jon (2002) 'Analyzing interaction: Video, ethnography and situated conduct', in T. May (ed.), Qualitative Research in Action. London: Sage Publications.

Heath, Christian, Knoblauch, Hubert and Luff, Paul (2000) 'Technology and social interaction: The emergence of "workplace studies"', British Journal of Sociology, 51(2): 299-320.

Heath, Christian, Hindmarsh, Jon and Luff, Paul (2010) Video in Qualitative Research: Analysing Social Interaction in Everyday Life. London: Sage Publications.

Hester, Stephen and Francis, David (2003) 'Analysing visually available mundane order: A walk to the supermarket', Visual Studies, 18(1): 36-46.

Hindmarsh Jon and Heath, Christian (1998) 'Video and the analysis of objects in action', Communication \& Cognition, 31(2/3): 111-130.

Hindmarsh, Jon and Pilnick, Alison (2007) 'Knowing bodies at work: Embodiment and ephemeral teamwork in anesthesia', Organization Studies, 28(09): 1395-1416.

Knorr Cetina, Karin (2009) 'The synthetic situation: Interactionism for a global world', Symbolic Interaction, 32(1): 6187.

Kuzuoka, Hideaki, Pitsch, Karola, Suzuki, Yuya, Kawaguchi, Ikkaku, Yamazaki, Keiichi, Yamazaki, Akiko, Kuno, Yoshinori, Luff, Paul, and Heath, Christian (2008) 'Effect of restarts and pauses on achieving a state of mutual orientation between a human and a robot', CSCW'08, November 8-12, 2008, San Diego, California, USA.

Lee, J. R. E. and Watson, D. R. (1992) Interaction in Urban Public Space. Final Report, Paris: Plan Urbain, unpublished.

Livingston, Eric (1986) The Ethnomethodological Foundations of Mathematics. London: Routledge and Kegan Paul.

Livingston, Eric (1987) Making Sense of Ethnomethodology. London: Routledge and Kegan Paul. 
Llewellyn, Nick (2015) 'Microstructures of economic action: Talk, interaction and the bottom line', British Journal of Sociology, 66(3): 486-511.Luff, Paul, Hindmarsh, Jon and Heath, Christian (eds.) (2000) Workplace Studies: Recovering Work Practice and Informing Systems Design. Cambridge, UK: Cambridge University Press.

Luff, Paul, Yamashita, Naomi, Kuzuoka, Hideaki, and Heath, Christian (2011) 'Hands on Hitchcock: Embodied reference to a moving scene', CHI 2011, May 7-12, 2011, Vancouver, BC, Canada.

Lutz, Catherine A. and Collins, Jane L. (1993) Reading National Geographic. Chicago, IL: University of Chicago Press.

Lynch, Michael and Edgerton, Samuel Y. (1988) 'Aesthetics and digital image processing: Representational craft in contemporary astronomy', in G. Fyfe and J. Law (eds.), Picturing Power: Visual Depiction and Social Relations, Sociological Review Monograph No. 35. London: Routledge and Kegan Paul. pp. 184-220.

Lynch, Michael and Sharrock, Wes (2003) 'Editors' Introduction', in M. Lynch and W. Sharrock (eds.), Harold Garfinkel. Sage Masters of Modern Social Thought, four volumes. London: Sage Publications. pp. vii-xlvi.

Mannay, Dawn (20XX) 'Revisualizing data: Enagement, impact and multimodal dissemination', in L. Pauwels and D. Mannay (eds.), The Sage Handbook of Visual Methods. (2nd Ed) London: Sage. pp. xx-xx.

Mauss, Marcel (1973) 'Techniques of the body', Economy and Society 2(1): 70-88.

Mead, Margaret (1975) 'Visual anthropology in a discipline of words', in P. Hockings (ed.), Principles of Visual Anthropology. The Hague: Mouton.

Merlino, Sara and Mondada, Lorenza (2018) 'Crossing the street: How pedestrians interact with cars', Language and Communication volume? Page range? doi.org/10.1016/j.langcom.2018.04.004

Mondada, Lorenza (2003) 'Working with video: How surgeons produce video records of their actions', Visual Studies, 18(1): $58-72$.

Mondada, Lorenza (2008) 'Using video for a sequential and multimodal analysis of social interaction: Videotaping institutional phone calls', Forum Qualitative Sozialforschung/Forum: Qualitative Social Research, 9(3), Art. 39. [Online]. Available from http://www.qualitative-research.net/fqs [Accessed 20 September 2010]. 
Psathas, George (1979) 'Some organizational features of direction maps', in G. Psathas (ed.), Everyday Language: Studies in Ethnomethodology. New York: Irvington. pp. 203-225.

Rawls, Anne (2002) 'Editor's introduction', in H. Garfinkel (ed.), Ethnomethodology's Program: Working Out Durkheim's Aphorism, edited and introduced by A. W. Rawls. Lanham, MD: Rowman and Littlefield.

Robinson, Dwight E. (1976) 'Fashions in shaving and trimming of the beard: The men of the Illustrated London News, 1842-1972', American Journal of Sociology, 81(5): 1133-1141.

Rodriguez, Noelie and Ryave, Alan (2002) Systematic Self-Observation. Thousand Oaks, CA: Sage.

Ryave, A. Lincoln and Schenkein, James N. (1974) 'Notes on the art of walking', in R. Turner (ed.), Ethnomethodology. Harmondsworth: Penguin. pp. 265-274.

Sacks, Harvey (1972) 'Notes on police assessment of moral character', in D. Sudnow (ed.), Studies in Social Interaction. New York: Free Press. pp. 280-293.

Sacks, Harvey (1992) Lectures on Conversation. Oxford: Blackwell.

Sacks, Harvey, Schegloff, Emanuel A. and Jefferson, Gail (1974) 'A simplest systematics for the organization of turntaking in conversation', Language 50(4): 696-735.

Schegloff, Emanuel A. (1972) 'Notes on a conversational practice: Formulating place', in D. Sudnow (ed.), Studies in Social Interaction. New York: Free Press.

Schegloff, Emanuel A. (1987) 'Description in the social sciences I: Talk-in-interaction', Papers in Pragmatics, 2: 1-24. Schegloff, Emanuel A. (2000) 'On granularity', Annual Review of Sociology, 26: 715-720.

Sharrock, Wesley W. and Anderson, Digby C. (1979) 'Directional hospital signs as sociological data', Informational Design Journal, 1(2): 81-94.

Sharrock, Wesley W. and Coulter, Jeff (2003) 'Dissolving the "projection problem”', Visual Studies, 18(1): 73-82.

Sharrock, Wes and Greiffenhagen, Christian (2017) 'Searching for ideas in working up a visual image', International Review of Qualitative Research, 10(2): 149-171. DOI: 10.1525/irqr.2017.10.2.149 
Signorelli, Vito (1984) 'Capitulating to the captions: The verbal transformation of visual images', Human Studies, 10: 281-310.

Slack, Roger, Hartswood, Mark, Procter, Rob and Rouncefield, Mark (2007) 'Cultures of reading: On professional vision and the lived work of mammography', in S. Hester and D. Francis (eds.), Orders of Ordinary Action: Respecifying Sociological Knowledge. Aldershot: Ashgate. pp. 175-193.

Sormani, Philippe (2016) 'Practice-based video analysis: A position statement', SocietàMutamentoPolitica, 7: 103120. DOI: $10.13128 / S M P-19698$

Sudnow, David (1972) 'Temporal parameters of interpersonal observation', in D. Sudnow (ed.), Studies in Social Interaction. New York: Free Press.

Sudnow, David (1978) Ways of the Hand. London: Routledge and Kegan Paul.

Sudnow, David (2001) Ways of the Hand: A Rewritten Account. Cambridge, MA: MIT Press.

ten Have, Paul (1999) Doing Conversation Analysis. London: Sage Publications.

ten Have, Paul (2003) 'Teaching students observational methods: Visual studies and visual analysis', Visual Studies, 18(1): 29-35.

Vertesi, Janet (2012) 'Seeing like a Rover: Visualization, embodiment, and interaction on the Mars Exploration Rover Mission', Social Studies of Science, 42(3): 393-414.

Watson, Rodney (2005) 'The visibility arrangements of public space: Conceptual resources and methodological issues in analyzing pedestrian movements', Communication and Cognition, 38(3/4): 201-228.

West, Candace (1984) Routine Complications: Troubles with Talk between Doctors and Patients. Bloomington, IN: Indiana University Press.

Williamson, Judith (1978) Decoding Advertisements. London: Marion Boyars. 